
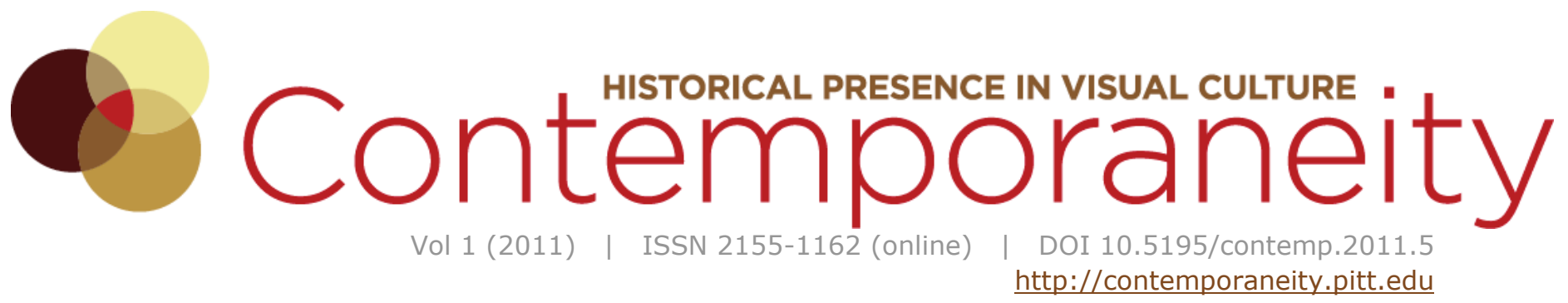

\title{
Transcultured Architecture: Mudéjar's Epic Journey Reinterpreted
}

\author{
Ila Nicole Sheren
}

\begin{abstract}
The Mudéjar phenomenon is unparalleled in the history of architecture. This style of architecture and ornamentation originated with Arab craftsmen living in reconquered medieval Spain. Embraced by Spanish Christians, Mudéjar traveled over the course of the next four centuries, becoming part of the architectural history of Latin America, especially present-day Mexico and Peru. The style's transmission across different religions and cultures attests to its ability to unify disparate groups of people under a common visual language. How, then, did mudejar managto gain popularity across reconquered Spain, so much so that it spread to the New World colonies? In this article, I argue that art and architecture move more fluidly than ideologies across boundaries, physical and political. The theory of transculturation makes it possible to understand how an architectural style such as Mudéjar can be generated from a cultural clash and move to an entirely different context. Developed in 1947 by Cuban scholar and theorist Fernando Ortíz, transculturation posited means by which cultures mix to create something entirely new. This process is often violent, the result of intense conflict and persecution, and one culture is almost always defeated in the process. The contributions of both societies, however, coexist in the final product, whether technological, artistic, or even agricultural. I argue that mudejar in Latin America is a product of two separate transculturations: the adoption of Arab design and ornamentation by Spanish Christians, and the subsequent transference of these forms to the New World through the work of indigenous laborers.
\end{abstract}

\section{About the Author}

Ila Nicole Sheren received her PhD from MIT's Department of Architecture in May 2011 and will be a Mellon Postdoctoral Fellow at the University of Toronto's Jackman Humanities Institute. 


\section{Transcultured Architecture:}

\section{Mudéjar's Epic Journey Reinterpreted}

\author{
Ila Nicole Sheren
}

The Mudéjar phenomenon is unparalleled in the history of architecture. This style of architecture and ornamentation originated with Arab craftsmen living in reconquered medieval Spain. Embraced by Spanish Christians, Mudéjar traveled over the course of the next four centuries, becoming part of the architectural history of Latin America, especially present-day Mexico and Peru. The style's transmission across different religions and cultures attests to its ability to unify disparate groups of people under a common visual language. To complicate matters further, Mudéjar is an architectural style with no internal cohesion or governing theory, a term that, for some, fails to qualify as a "style" in itself. Art and architectural historians speak of Mudéjar "fragments" and "reminiscences," describing wooden geometric ceilings or patterns of ornamentation rather than entire structures or building programs. How, then, did Mudéjar manage to gain popularity across reconquered Spain, so much so that it spread to the New World colonies?

In this case, art and architecture move more fluidly than ideologies across boundaries, physical and political. The theory of transculturation makes it possible to understand how an architectural style such as Mudéjar can be generated from a cultural clash and move to an entirely different context. Developed by Cuban scholar and theorist Fernando Ortíz in 1947, transculturation, as opposed to the then-prevalent theory of acculturation, posited means by which cultures mix to create something entirely new. ${ }^{1}$ This process is often violent, the result of intense conflict and persecution, and one culture is almost always defeated in the process. The contributions of both societies, however, coexist in the final product, whether technological, artistic, or even agricultural. I would argue that Mudéjar in Latin America is a product of two separate transculturations: the adoption of Arab design and ornamentation by Spanish Christians, and the subsequent transference of these forms to the New World through the work of indigenous laborers.

Mudéjar originated in medieval Spain, shortly after the Reconquista. ${ }^{2}$ During the Moorish occupation of Spain, many Arab craftsmen were relocated to the territory, creating such iconic Islamic structures as the Great Mosque of Cordoba (784-987) and the fourteenth century Alhambra palace in Granada. After the Spanish recaptured the territory in 1492, many of these Muslims, now Christianized, were allowed to stay and work in Spain. The Spanish themselves encouraged this dynamic to different ends, guaranteeing degrees of freedom for Muslims. In 1267, the king of Valencia issued a proclamation declaring that any Muslim coming to the city would "remain there under protection...[and] 'practice his craft."'3

\footnotetext{
${ }^{1}$ Acculturation was first defined in the 1930 s by the anthropological team of Redfield, Linton, and Kerskovits; it "comprehends those phenomena which result when groups of individuals having different cultures come into continuous firsthand contact, with subsequent changes in the original cultural patterns of either or both groups." Robert Redfield, Ralph Linton, Melville J. Herskovitz, "Memorandum for the Study of Acculturation"American Anthropologist 38, 1936: 149.

2 The Spanish Reconquista took several centuries, from the capture of Toledo in 1085, Seville in 1248, and finally, the capture of Grenada in 1492. (See Gonzalo M. Borrás Gualis, "Mudéjar: An Alternative Architectural System In the Castilian Urban Repopulation Model" Medieval Encounters 12, 2006: 329-340).

3 Robert Ignatius Burns, Islam Under the Crusaders: Colonial Survival in the Thirteenth-Century Kingdom of Valencia (Princeton: Princeton University Press, 1973), 98.
} 
In Toledo, the intention of King Alfonso VI in his pact of 1085 was that the Muslims would remain in the city following the conquest, their rights to retain property and worship publicly in their mosques guaranteed. ${ }^{4}$ It is important to note, however, that these rights and religious freedoms were granted only after the perception of a Muslim threat had subsided. According to art historian David Raizman, Mudéjar "emerged not at the moment of conquest but more than a century later, when political and economic circumstances were more favorable to building, and when the incorporation or integration of Islamic forms could be seen as the visible counterpart to the image of a cosmopolitan Christian capital." ${ }^{5}$ In Spain, the adoption of Mudéjar was a conscious display of power on the part of the ruling establishment. Only when power was secured was tolerance extended toward Muslims in the reconquered lands.

The term Mudéjar comes from the Arabic word mudayyan, literally "one permitted to remain." The mudayyan, comprised largely of wood- and stoneworkers, continued to exert their influence on the Gothic and Baroque styles under Spanish rule. ${ }^{6}$ Design elements such as muqarnas, Islamicized horseshoe arches and geometrically patterned ceilings were often paired with Baroque columns and Gothic altarpieces within the same building. The term Mudéjar began to be used, along with the terms "hispano-arabic art," "hispano-muslim art," and "Moorish art," to describe this style of ornamentation found in Spain. ${ }^{7}$ Coined in 1859 by the Spanish scholar José Amador de los Rios, Mudéjar replaced "Moor" and "Arab" only after the religious and cultural heterogeneity of the Islamic world became evident to those studying it. In 1990, the Spanish architectural historian José Maria Azcárate attempted to do away with the term "Mudéjar" altogether, coining the phrase "arquitectura cristiana islamizada" (Christianized Islamic architecture) to replace it. ${ }^{8}$ The phrase was never fully accepted, but the term's unwieldiness was not the only issue at hand; art historians argued that the new phrase served as a cultural reference while "Mudéjar" functions to describe the visual arts. ${ }^{9}$ Although Azcárate's term quickly faded into obscurity, the need for

4 David Raizman, "The Church of Santa Cruz and the Beginnings of Mudéjar Architecture in Toledo," Gesta

38 (1999), 128-141.

5 Raizman, "The Church of Santa Cruz and the Beginnings of Mudéjar Architecture in Toledo," 138.

${ }^{6}$ Although Mudéjar ornamentation was originally attributed to Muslim craftsmen, it is now known that Christians, Muslims and Jews all worked on structures now considered to be Mudéjar.

7 Leon R. Zahar, "Los Nombres del Arte del Islam," Artes de Mexico 55 (2001), 38. "Arab," "Muslim," or "Moor" became inadequate to describe this category of Christianized Muslims, and the earlier terms were gradually replaced by "Mudéjar" in the scholarship. The result is that Mudéjar can be used to describe a style of architecture and the people who originated it. Today, "morisco/moor" and "Mudéjar" are often used interchangeably, but there is disagreement on this distinction or lack thereof.

8 Gonzalo M. Borrás Gualis, "Introducción," Arte Mudéjar (Zaragoza: UNESCO \& Ibercaja, 1995), 19. This failed attempt to rename the style is also discussed in Borrás Gualis' chapter "El arte mudéjar: estado actual de la cuestion." in the book Mudéjar Iberoamericano: un expresión cultural de dos mundos (Ignacio Henares Cuellar and Rafael López Guzmán, eds).

9 It may seem contradictory that an architectural historian proposed a cultural term to define an artistic style and thereby accrued criticism from the art and architectural history community. José Maria Azcárate, however, is an architectural historian specializing in the Spanish Gothic and does not consider Mudéjar an autonomous style. In any event, the attempt at changing the name did not succeed; "Mudéjar" is still the term used today by Spanish and Latin American scholars. 
terminological clarification continued, raising questions as to Mudéjar's cultural and aesthetic origins.

Mudéjar was first characterized as a style in 1888, when the Spanish art historian Pedro de Madrazo distinguished it as a widespread phenomenon, not just the signature work of certain artists or craftsmen. ${ }^{10}$ In calling it a style, de Madrazo claimed for Mudéjar the same significance that had previously been given to the Baroque or the Rococo. In the majority of examples, however, this autonomy was simply not observable. The greatest problem of this claim for stylistic independence was that Mudéjar could co-exist with other styles in the same building. In this vein, it is possible to find examples of Baroque structures with Mudéjar ceilings and Renaissance buildings with Islamicized geometric ornament. From this perspective, it seems that Mudéjar is not a style of its own, but rather certain elements of design that can coexist with the architecture of an established period. For Spanish art historian Gonzalo M. Borrás Gualis, Mudéjar "always existed at the margins of Western European architectural styles, which were reserved for cathedrals." ${ }^{11}$ This description of Mudéjar "at the margins" is not limited to Europe; Mudéjar existed on the periphery of Spain in its New World colonies, as well as on the frontier of Islamic architecture.

The question remains, though, as to what extent Mudéjar can be considered Islamic architecture. According to Oleg Grabar, the word "Islamic" implies religion; it "misrepresents the values of an artistic creativity which was much richer than whatever is involved in religious thought...and which included aspects of life and forms of behavior incompatible with the precepts of the faith."12 Following this point, it is conceivable that Islamic art could cover structures built by and for non-Muslims, including the churches of the newly reconquered Spanish cities. Grabar, in an earlier work on Islamic art, outlined three themes common to all art labeled "Islamic": social meaning, abstract ornament, and the tension between unity and plurality. ${ }^{13}$ Mudéjar ornament engages the second two themes, albeit on a smaller scale than more traditional Islamic art. By "social meaning," however, Grabar refers to Islamic art and its tendency to monumentalize "more settings for social activities" than any other civilization since ancient Rome. ${ }^{14}$ This function is absent from most Mudéjar structures, which are primarily religious. Grabar himself is unable to decide on Mudéjar's status, citing the "paradoxical ethos in which intense identification of differences between groups and allegiances...coexisted with open-minded cohabitation and creative inventiveness" on the Spanish "frontier." ${ }^{15}$ In other words, Mudéjar is the product of two conflicting interests

10 Borrás Gualis, "Introducción," 16. Mudéjar architecture was originally considered to be the architecture (or crafts) of the moriscos, thus limited to a specific group of people. By the 1930s, however, ample evidence of Christian artisans involved with the production of Mudéjar works had been found in Spain, and the term came to designate the Moorish forms rather than the craftsmen themselves. For a fuller discussion of this, see David Raizman, "The Church of Santa Cruz and the Beginnings of Mudéjar Architecture in Toledo" in Gesta 38(2), 1999, pages 128-141.

11 Gonzalo M. Borrás Gualis, "Mudéjar: An Alternative Architectural System in the Castilian Urban Repopulation Model," Medieval Encounters 12 (2006), 336.

12 Oleg Grabar, "The Aesthetics of Islamic Art," Islamic Art and Beyond: Constructing the Study of Islamic Art, Vol. 3 (Burlington, VT: Ashgate, 2006), 335. The article was originally published in 1993.

13 Oleg Grabar, "What Makes Islamic Art Islamic?" Islamic Art and Beyond: Constructing the Study of Islamic Art, Vol. 3 (Burlington, VT: Ashgate, 2006), 248. In an essay published originally in 1976, Grabar attempts to find the commonalities in all Islamic art that fall outside the purview of religion.

14 Ibid.

15 Oleg Grabar, "Two Paradoxes in the Islamic Art of the Spanish Peninsula," The Legacy of Muslim Spain, ed. Salma Khadra Jayyusi (New York: E.J. Brill, 1992), 590. 
working together: Spanish Christians and conquered Muslim workers. This "creative inventiveness" found on the frontier is not entirely different from literary theorist Walter D. Mignolo's concept of "border thinking" - the specialized knowledge generated from the periphery or borderlands. ${ }^{16}$ Although Mudéjar comes from the border zone of Islamic art and architecture, it contributes another layer of meaning to Islamic art as a whole. Mudéjar and its process of transmission across cultures demonstrates how certain key features of Islamic art transcend religion, culture and ideology. The resulting art belongs as much to the originating culture as it does the receiving one. Following this argument, one can conclude that Mudéjar may be claimed to be both Islamic and European art.

Transculturation is the process most accurately used to describe this movement of art and design across cultures. This term was coined by the Cuban essayist, ethnomusicologist and scholar Fernando Ortíz, who dedicated his career to understanding all aspects of indigenous Cuban culture. ${ }^{17}$ In general, transculturation implies a natural tendency of people to resolve, rather than exacerbate, conflicts over time. ${ }^{18}$ With the rise of communication and technological innovation, the forces bringing cultures together are stronger than those pushing them apart. ${ }^{19}$ This kind of integrationism was intertwined with Cuba's political situation at the time, conceived as "the articulation of a republican citizenry, with equal civil, social, and political rights, freely manifesting its cultural heterogeneity." ${ }^{20}$ As described in 2005 by Felipe Hernández, the process is multi-directional and endless, a series of interactions between cultural systems that is in opposition to unidirectional and hierarchical structures associated with claims to cultural authority. ${ }^{21}$

In his 1947 book Cuban Counterpoint: Tobacco and Sugar, Ortíz laid out two examples of transculturation as it applied to Cuban agriculture. Tobacco, a crop native to the island but soon demanded by white settlers for its "medicinal properties," underwent a transculturation of its own in moving from the New World to Europe. ${ }^{22}$ In order to increase governmental revenue through taxation, European authorities justified smoking through a number of measures including exploiting its so-called health benefits. The end result was a product used in different ways (and for different purposes) according to the local customs. Sugar, on the 16 Walter D. Mignolo, Local Histories/Global Designs: Coloniality, Subaltern Knowledges and Border
Thinking (Princeton: Princeton University Press, 2000), 5.

17 July 16, 1881 - April 10, 1969. Although transculturation was coined to refer specifically to Cuba and its indigenous people, the term has since been used to refer to the process of knowledge transmission between any two cultures.

18 "Ethnoconvergence" is another term used in tandem with transculturation, referring to situations in which transculturation impacts ethnic issues.

19 Fernando Ortíz, Cuban Counterpoint: Tobacco and Sugar (New York: Knopf, 1947), 102-103.

20 In 1947, Cuba was in-between the two Batista regimes and some manifestations of the popular will were allowed to take place. The Cuban Peoples' Party was formed that year, and Fidel Castro participated in the Bogotazo uprising. Rafael Rojas, "Fernando Ortíz: Transculturation and Nationalism," Essays in Cuban Intellectual History (New York, Palgrave Macmillan, 2008). While Rojas is making a nationalist claim rather than an aesthetic one, the connection between transculturation and the political system it has come out of is something not to be ignored.

21 Felipe Hernández. "Introduction," Transculturation: Cities, Spaces and Architectures in Latin America (New York: Rodopi, 2005), xi.

22 Ortíz, Cuban Counterpoint: Tobacco and Sugar, 198. The European emphasis on the purported medicinal qualities of tobacco was an attempt to justify the act of smoking according to the prevailing Renaissance morality. Until then, smoking tobacco had been viewed as a pastime for criminals and the lower rungs of society. 
other hand, is found all over the world, but European colonists optimized its growing conditions in Cuba, reapportioning large tracts of land for cultivation and relying on a large slave population for labor. The sugar-based economy on the island is a result of a three-way transculturation between Europeans, Africans, and native Cubans. Ortíz argued that in each of these cases, the end product belonged to no culture exclusively, but to all of them in part. The process he described is twofold: deculturation, the "loss or uprooting" of a previous culture, followed by neoculturation, the "consequent creation of new cultural phenomena." 23 These "new phenomena" owe their existence to the original cultural conflict.

To return to the example of Mudéjar in Spain, transculturation began as an attempt to re-appropriate Islamic religious structures to Christian purposes. Rather than the wholesale destruction of mosques, the Spanish rulers encouraged conversion of the buildings to churches. Although the forms of worship taking place in mosques are vastly different from Christian religious ceremonies, the basic plans of the buildings were retained. ${ }^{24}$ As a result, each reconquered city in Spain boasted several former mosques, as well as a number of secular buildings that provided a template for Islamic ornamentation and design. The process of transculturation begins when one considers the interaction between the Spanish and Islamic contributions, and how they work together to create a new style.

As stated earlier, the Islamic design elements in Mudéjar are geometric and abstract ornament, surface patterning, and the concept of unity, but what were the Spanish contributions? The most visible contribution is that these Islamic design elements can coexist with Christian decoration and themes. Mudéjar structures also boast a greater number of carved inscriptions than do Christian buildings throughout the rest of Europe, a direct result of Islamic influence. On a much broader level, however, Spain is integral to the development of Mudéjar; similar architectural combinations failed to occur in other formerly Islamic regions, such as Sicily, the Balkans, or even Russia. ${ }^{25}$ For Mudéjar to develop, the Spanish had to be particularly receptive to outside influence. The prevailing Christian architectural style at the time, the Gothic, stressed height, light, and abstracted figuration. While Spain adopted the Gothic immediately following the reconquest, the recently converted mosques did not lend themselves to this style. With the abundance of pre-existing structures and workers trained in Islamic ornamentation, the Spanish were able to adopt the new forms once their power had been consolidated. The end product of this transculturation process is Mudéjar - built by Muslims, Christians and Jews for religious and secular purposes alike - a true hybrid architecture.

The story of Mudéjar is further complicated by its adoption in Latin America. As stated earlier, José Amador de los Rios originally defined Mudéjar as limited to the architectural elements first developed by Christianized Muslims living in Spain after the Reconquista. ${ }^{26}$ This fact is noteworthy because Mudéjar was identified only in relation to the bodies of the workers who executed the work, rather than geographic location or patronage. In the

\footnotetext{
23 Ortíz, Cuban Counterpoint, 102-3. The complexity of his argument is opposed to the simplicity of the dominant term at the time, acculturation, which referred to the complete submission of one culture to another. In his example, Ortíz claimed that the acculturation model completely ignores the contributions of Africans and Cuban natives, not to mention the island of Cuba itself.

24 The Spanish constructed entirely new buildings in the Gothic style for the cathedral in each city. Reconverted mosques were used primarily as subsidiary or parish churches.

25 Grabar, "Two Paradoxes in the Islamic Art of the Spanish Peninsula," 588. These regions had much stronger local culture, art and design than Spain had prior to the Muslim occupation.

26 Borrás Gualis, "Introducción," 16.
} 
discussion of Latin American Mudéjar, the workers' bodies (this time indigenous) once again define the style. With the capture of Grenada in 1492, the reconquest of Spain was complete, coinciding with Columbus' first voyage across the Atlantic. At the same time that Mudéjar emerged in Europe, Spain spread its influence to the New World. In its colonies in the Americas, the Spanish Empire began a vast building program that included the construction of new cities. Mudéjar, then gaining traction in Spain, was one of the major styles exported to the colonies. With the addition of Latin America to the story of Mudéjar, new questions arise - how is Latin American Mudéjar related to the original in Spain? How does it fit under the greater umbrella of "Islamic" art and architecture?

The Church of San Miguel in Sucre, Bolivia, provides an example of Latin American Mudéjar in situ. The open floor plan of this chapel is derived from Spanish mosques and typical of Mudéjar in Latin America. Its octagonal form and patterned wooden ceiling, or cubierta (covering) reflect the Islamic preoccupation with geometry. ${ }^{27}$ The undersides of the supporting arches are carved with a vegetal motif that recalls the arabesque. Around the octagonal dome are more wooden ceiling panels, each carved with a larger version of the dome's cubierta. The expansion and multiplication of an initial pattern is a theme found throughout Islamic art and architecture; San Miguel is a direct inheritor of this tradition. These Mudéjar elements are situated within a larger Baroque framework. Plain white stucco walls stand in direct contrast to the highly decorative woodwork, while the elaborate gilded altarpiece seems to provide a visual counterpoint. Mudéjar and Baroque coexist uneasily within the structure; white space and undulating masses compete with the intricate patterning, while the overall spectacle defies easy classification.

Many scholars, equating Latin American Mudéjar with that of Spain, choose to use the same term when describing both regions. This terminological similarity fails to distinguish the Islamic elements present in Spain that differ from those appearing in the architecture of its former colonies. To differentiate the two phenomena, Borrás Gualis uses the term "pervivencias Mudéjares," (Mudéjar survivals) stating that "it is impossible to apply the definition of Mudéjar to the New World and other Spanish territories." 28 Other scholars, including Mexican art historian Manuel Toussaint, have pushed for usage of the term "reminisencias Mudéjares" (Mudéjar reminiscences) instead. It is not an accident that these two phrases have been chosen to describe the style.

This discrepancy raises the issue of whether the story of Mudéjar's transplantation across the Atlantic is one of artistic survival or of cultural memory. At stake here is a reinterpretation of the narrative of conquest, this time envisioned through the context of architectural style. Although the words "reminiscences" and "survival" refer to the same phenomenon - the presence of Mudéjar decorative elements in Latin American architecture they imply fundamentally different processes of change, one passive, the other active, one dominated by the conquerors, the other by the conquered.

\footnotetext{
27 The ceilings of many Latin American churches have two shells, an outer and inner. For aesthetic effect, the inner shell was often intricately carved from wood. For a detailed mathematical investigation of Islamic design, see Chapter 2 of John R. Moffitt's, The Islamic Design Module in Latin America (2004). The book itself is an argument for Pythagorean triangulation in Hispano-Islamic design "modules."

28 Borrás Gualis, "Introducción," 28. This attitude reflects not only perceived architectural autonomy from Spain, but also underscores the political distinctions as well.
} 
From a survey of the written material on Latin American Mudéjar, two distinct trajectories emerge from separate disciplinary foundations. ${ }^{29}$ The main focus of these narratives is the transmission of architectural forms from one culture to another. In the case of this style, origins and identity are inextricably linked to the methods of transmission between cultures. The first approach, typical of art historians, deals with the visual forms of Mudéjar and the question of whether or not it constitutes an autonomous architectural style in Latin America. The confusion of Mudéjar's origins and status in Spain were only compounded by the journey across the Atlantic. In general, art and architectural historians refer to Mudéjar as it applies to the art forms, not the culture or the people that produced it. This school of thought is the one that deals most thoroughly with building types, materials, and classification of ornament. ${ }^{30}$

Art historians also seek to contextualize Latin American Mudéjar within the established canon. The periods and dates involved are those specific to Latin America, for the transmission of styles across the Atlantic could take as long as fifty years to accomplish. ${ }^{31}$ In Spain, Mudéjar coincided with the Gothic, Renaissance, and Baroque, and Mudéjar elements are found on buildings from each of these styles. Officially, Mudéjar ended with the expulsion of converted Muslim craftsmen in the seventeenth century. In Latin America, the style can be categorized as coexisting with the Baroque, ${ }^{32}$ which generally falls into the Colonial Period (1492-1820), but because it was not tied to a particular ethnic group Mudéjar has lasted well past the $18^{\text {th }}$ century, even turning up in some present-day buildings as "neo-Mudéjar." 33 The Baroque was the main architectural style exported from Spain at the height of its conquest, and consequently the majority of architecture and urban space fits into this period. The question remains, however, as to whether Latin American Mudéjar is a subcategory of the Islamic art, European Baroque ${ }^{34}$ or whether it constitutes a style of its own. With Latin

29 For reference, see the Artes de Mexico issues devoted to Mudéjar (\#54 \& 55, 2001) which contain articles related to the transmission debate, and also Mudéjar Iberoamericano: una expresión cultural de dos mundos, ed.Ignacio Henares Cuellar and Rafael López Guzmán (Granada: Universidad de Granada, 1993); Arte Mudéjar (Zaragoza: UNESCO \& Ibercaja, 1995) contains country-specific articles detailing the differences in Mudéjar throughout Central America, South America, and the Caribbean. For a site-specific study of Mudéjar remains in Latin America, see Pablo C. de Tante, "Mudéjar Reminiscences in Queretaro," Mexican Art and Life, 5 (1939); for a more archaeological perspective, see T. B. Irving, "Mudéjar architectural remains in the Americas," Muslim and Arab Perspectives 1 (1994); for an especially detailed survey of Mudéjar's history from Spain to its arrival in Latin America, see Rafael López Guzmán, Arquitectura Mudéjar: del sincretismo medieval a las alternatives Hispanoamericas (Madrid: Ediciones Cátedra, 2000).

30 At this early point in the study of Latin American Mudéjar, however, the writing on this subject consists mainly of monographs rather than more theoretical works. Art historians dealing with Latin American Mudéjar are still surveying the available material and attempting to catalogue and ultimately characterize the style.

31 Rafael López Guzmán, Arquitectura Mudéjar: del sincretismo medieval a las alternatives Hispanoamericas (Madrid: Ediciones Cátedra, 2000), 425.

32 1600-1720 are the generally accepted dates for European Baroque; Latin American Baroque continued well into the $19^{\text {th }}$ century, until the time of the major independence movements.

33 Neo-Mudéjar is both an extension of the Mudéjar style in Latin America and also a product of the revival movement that began in the late $19^{\text {th }}$ century. It is telling that Mudéjar was by then so accepted into local architectural history that it was considered among the "national" styles to be revived.

34 Art historians developed the term "baroco-mudéjar" to describe the hybrid style. 
American Mudéjar, I would argue that rather than a single style, Mudéjar of this region represents a hybrid of European, Islamic and indigenous art.

Aside from the art historical debate as to the stylistic nature and categorization of Mudéjar, cultural anthropologists and historians alike have dealt with the narrative of its origins in Latin America. This narrative of Mudéjar's journey across the Atlantic characterizes the cultural clash rather than simply describing the style's visual qualities. The major Latin American cultural contact theories of the twentieth century play a significant role, specifically Fernando Ortíz' theory of transculturation and Néstor García Canclini's work on hybrid cultures. These contact theories have helped to recast the story of Mudéjar within the larger sphere of cultural contact and the transmission of ideas. Transculturation looks at two sides: Spain's role as agent of artistic transmission and the style's reception by indigenous peoples. The unique cultural interactions form the second step in the movement of Islamic design elements and ornamentation to Spanish architecture and, after conquest, to its colonies.

In 1995, the theory of transculturation was updated to reflect the status of Latin America as engendering a new kind of postmodernity. That year, Néstor García Canclini, in his influential study Hybrid Cultures, embraced the combinations of European and indigenous elements found in late twentieth-century Latin American culture. ${ }^{35}$ According to García Canclini, the end result of transculturation is cultural hybridity, with disparate elements coexisting and uniting to form a distinct society. Although this theory is a product of latetwentieth century postmodern thinking, it is a logical extension of Ortíz' transculturation, which was based on nineteenth-century observations. It is therefore not a stretch to apply the theory of transculturation to the transmission of Mudéjar to Latin America and even construe the early Spanish colonial period as a precursor to the "hybrid cultures" model that exists today.

That same year, Ramon Gutiérrez of the Instituto de Investigaciones Geohistoricas de Resistencia in Argentina, in an article written for UNESCO, applied the transculturation theory to the origins of Mudéjar. He described a process by which certain elements of the dominant culture are transferred to the occupied one. ${ }^{36}$ The process is not linear, and must be distinguished from simple transmission. ${ }^{37}$ Gutiérrez traces the method of transculturation from Spain to Latin America and gives special agency to the institutions of the state and religion, which were the two most powerful Spanish influences in the colonies. ${ }^{38}$ The process, as he describes it, is still poorly defined when applied to Latin American Mudéjar. A brief account of the mechanism is that certain elements of government, society, and art are better suited for the new territory and more readily adopted by the occupied culture. Rather than engage in a struggle to regain dominance, the occupied culture accepts these elements, absorbing and appropriating them. Eventually, these foreign elements are considered to be

35 Néstor García Canclini, Hybrid Cultures: Strategies for Entering and Leaving Modernity, trans. Christopher L. Chiappari and Silvia L. López (Minneapolis: University of Minnesota Press, 1995). García Canclini's theory, especially his insistence that Latin America and postmodern hybridity are inextricably linked, is one of the most widely accepted today.

36 Ramon Gutiérrez "Transferencia y presencia de la cultura islamica en America Latina a traves de la Peninsula Iberica." Arte Mudéjar (Zaragoza: UNESCO \& Ibercaja, 1995), 151.

37 Ibid. 155. For Ortíz' initial theory of transculturation and how it differs from linear transmission, see his seminal work Cuban Counterpoint: Tobacco and Sugar, Duke University Press, 1995.

38 Ramon Gutiérrez "Transferencia y presencia," 156. 
an integral part of the culture, as if they had always been a part of it. ${ }^{39}$ In the case of architecture, specifically, there is no way to predict which elements will survive the process of transculturation. To complicate matters further, Mudéjar's transculturation in Latin America was already its second time passing through the mechanism. Initially, Islamic art and architecture had undergone the same process during the Reconquista with the forced conversion of Muslims and the adoption of Islamic art into Christian structures.

The case of carpentry provides a concrete example of how this theory deals with Mudéjar. Carpentry was the most prominent medium for the style in Latin America, for the vast majority of ceiling- and balcony-work was made of wood. ${ }^{40}$ Historian Enrique Capablanca traced the specific situation in Cuba, where indigenous architecture was "practically naked" - a blank slate for Spanish influence. ${ }^{41}$ Mudéjar ceilings had already undergone the transculturation process from Islamic architecture to that of Spain. When the Spanish settled in Cuba their religious structures necessitated the kind of ornamentation and detail that, according to Capablanca, was ill-suited to the austere nature of the indigenous structures. ${ }^{42}$ The dominant Spanish culture stepped in to fill this void in the occupied culture. The natural abundance of wood in the Caribbean, along with the suitability of Mudéjar forms to this medium, allowed for the development of elaborate wooden ceilings. Over time, the wooden ceilings "lost all the ideology carried with [them] from Spain." ${ }^{43}$ This claim by Capablanca addresses the Cuban appropriation of these previously Spanish forms, although in reality the patterned ceilings have never lost the connotation with either Spain or the Islamic world. The ceilings are inextricably linked to the story of their transmission - the intricate ornamentation carries its history in the details.

The previous narrative centered on the Spanish side of transculturation, but there exists another approach - an indigenous-centered theory of the origins and transference of this building style. In other words, what did the native craftsmen in the Americas add to Latin American Mudéjar? The most prominent theorist from this perspective, Rafael López Guzmán, a prominent Spanish historian at the University of Granada, writes of the "medieval syncretism between Islam and Hispanoamerica." ${ }^{44} \mathrm{He}$ and other scholars writing along these lines portray the indigenous craftsmen as the driving force behind the development of

39 Gutiérrez, "Transferencia y presencia de la cultura islamica en America Latina a traves de la Peninsula Iberica," 156-7.

40 Rafael López Guzmán, "Mudéjar Iberoamericano: una expresión cultural de dos mundos," Mudéjar Iberoamericano: una expresión cultural de dos mundos, eds. Ignacio Henares Cuellar and Rafael López Guzmán, (Granada: Universidad de Granada, 1993), 191. For a detailed treatment of Mudéjar carpentry see Enrique Nuere's article "La carpinteria en España y America a traves de los tratados," Mudéjar Iberoamericano: una expresión cultural de dos mundos, eds. Ignacio Henares Cuellar and Rafael López Guzmán (Granada: Universidad de Granada, 1993). Nuere stresses the importance of carpentry for the Mudéjar while trying (and failing) to discover a link between the medium itself and the Muslim religion.

41 Enrique Capablanca, "La carpinteria mudéjar en Cuba." Mudéjar Iberoamericano: una expresión cultural de dos mundos, eds. Ignacio Henares Cuellar and Rafael López Guzmán (Granada: Universidad de Granada, 1993), 233. Here, the phrase "practically naked" (practicamente desnuda) is used to refer to the undecorated character of indigenous architecture and not as a derogatory comment on its quality.

42 Ibid, 233. These structures were also impermanent, lavishing such ephemeral buildings with excessive detail would have been impractical at best.

43 Ibid, 246. Carpentry became not just a profession for white Spaniards, but also a form of expression for native Cubans.

44 Rafael López Guzmán, Arquitectura Mudéjar: del sincretismo medieval a las alternatives Hispanoamericas (Madrid: Ediciones Cátedra, 2000), 425. 
Mudéjar in this region. Instead of focusing primarily on the continuance between Spain and the New World, this approach deals with the stylistic changes that took place and the distinctions that separate Latin American Mudéjar from that of Spain. According to López Guzmán, the process of artistic transference was a two-way street, rather than the simple imposition of Spanish art and culture on a receptive native people. As he states, "the indigenous craftsmen did not only dominate a series of techniques that were adapted to the necessities of the Spaniards, but also knew perfectly the distinct species of trees and their construction possibilities." 45 In the case of this scholarly approach, specified knowledge grants agency to the occupied culture, not the conquering one. If knowledge is power, then the traditional roles become reversed, with the conquered craftsmen holding the keys to successful building in their environment, rather than having a building style imposed completely upon them. ${ }^{46}$

In the example of carpentry, the indigenous-centered approach would treat the same observation - the prevalence of wooden ceiling covers in Mudéjar buildings - from an entirely different perspective. It would argue that the Spaniards arrived in their colonies with certain ideas about architectural aesthetics, derived from their native architecture. When faced with the specifics of Latin American climate and available building materials, the Spanish had to access that specialized knowledge in order to build successfully. Mudéjar ceilings were, as a result, constructed of wood, leading carpentry to become synonymous with Latin American Mudéjar. The problem is best stated by Enrique Nuere, professor of the history of construction at the Escuela Tecnica Superior de Arquitectura in Madrid. He writes "carpentry may appear to be obviously Mudéjar, but there is no apparent link to the environment of Islam." Basically, carpentry's association with Islam in Latin America is purely a function of its presence in Mudéjar structures, rather than any inherent religious attributions to the properties of wood. ${ }^{47}$ It has been argued that local woodcarvers in Latin America, with their knowledge of native trees, would have adapted their indigenous woodworking techniques to the specific requests of the Spaniards.

Identification of the indigenous contribution to Latin American Mudéjar began as early as 1948 with Alfred Neumeyer's attempts to define a true "mestizo" style. ${ }^{48}$ According to Neumeyer, its roots were not to be sought primarily "in an adaptation of Islamic-Spanish Mudéjar, or any other art style, but in that psychological situation created by the meeting of European Christianity with Indian paganism that must lead to specific visual concepts." 49

45 Ibid, 455. Indigenous people had access to information about the terrain and climate as well, factors that drastically affected the architectural outcome.

46 This is not a complete reversal of the power structure, since the style is still imported through the conquering culture, but it does grant the indigenous craftsmen a degree of agency not traditionally allotted to them in the other transmission theories.

47 Enrique Nuere, "La carpinteria en España y America a traves de los tratados." Mudéjar Iberoamericano: una expresión cultural de dos mundos, ed. Ignacio Henares Cuellar and Rafael López Guzmán (Granada: Universidad de Granada, 1993), 173. Meaning there is nothing specifically "Islamic" about carpentry. This is neither new nor groundbreaking. There are few, if any, architectural forms or elements that are considered to be fundamentally "Islamic." For the canonical work on this subject, see Oleg Grabar's detailed analysis, The Formation of Islamic Art (Yale University Press, 1978).

\footnotetext{
48 Alfred Neumeyer, "The Indian Contribution to Architectural Decoration in Spanish Colonial America," The Art Bulletin 30 (1948), 104-121. See José Vasconcelos' La Raza Cosmica (1925) for the original theory and definition of mestizaje, or the idea that all races would eventually blend into a single cosmic race to be located in Latin America.

49 Ibid, 108. Native techniques and Mudéjar form only provided basic patterns, while the final form was caused by new ideological configurations.
} 
Indigenous workers could relate to Spanish-Islamic Mudéjar ornament, as their own cultures had made use of geometric and abstract patterning. In many cases, such as the church of San Miguel mentioned earlier, the woodcarving is flatter than similar patterns found in Spain. The difference is in the execution of the forms and the aesthetic preferences of the workers themselves. Vegetal ornament, such as flowers and leaves, also resembles its more abstract counterparts on indigenous temples and other building complexes. ${ }^{50}$

Clearly, the issue here is one of agency; this indigenous-centered approach deals with questions of identity, both national and cultural. What are the relative roles of Muslim, Spanish, and indigenous workers, and how has it been possible for Mudéjar to belong to all three cultures? More problematically, the separation of these distinct cultural identities is a shift away from the Latin American ideological tendency to view the region as an undifferentiated mix of previously distinct cultures. It is now necessary to contend with these distinct identities, assessing the contributions of each when related to the whole of a style or movement.

Applying these approaches to the terminological confusion - reminisencias Mudéjares versus pervivencias Mudéjares - it is possible to examine how each of these labels can function as an appropriate characterization. The basic forms of Islamic ornamentation survive the process of transculturation not once, but twice in order to exist in their Latin American forms. Reminiscencia (reminiscence) implies a passive process, while pervivencia (survival) refers to something more active. The word survival is a charged term, implying a struggle between cultures and, ultimately, the superiority of those artistic elements that remain. Mudéjar is then the allegory of conquest played out in architectural forms. In this case, the Mudéjar elements are reminders of the Spanish past reinterpreted by indigenous builders and craftsmen through the agency of memory. For reminiscencia, however, the case could be argued instead that the fragments that survive are part of an inherited Spanish cultural memory interpreted through the work of the indigenous culture. Although reminiscence connotes a mostly passive process, it is the physical work of the indigenous craftsmen that remains, granting greater agency to the occupied culture. For the larger realm of art history, both terms seem too abstracted for the task at hand. In both cases survival and reminiscence - the descriptive terms are more suited to a cultural understanding rather than a purely visual/art historical one.

Another major question arises when considering Mudéjar as a process of transculturation, namely, the application of this ostensibly Cuban theory to completely different cultures. Some theorists have argued that transculturation was never intended to move beyond the Cuban context, and that it must be continually redefined in order to apply to other situations. ${ }^{51}$ Such a narrow definition of transculturation, however, ignores Ortíz' original purpose with his theory - a more accurate description of the dynamics of cultural contact. The previous acculturation model granted no agency to the conquered or defeated culture, assuming that the conqueror completely absorbs the conquered. Transculturation added much-need nuance to the field, and allowed an explanation for the new knowledge produced from the clash of cultures. When redefined for the current context - the transmission of architectural forms across different cultures and religions - this model accounts for the initial development of Mudéjar and its transmission to the colonies.

\footnotetext{
50 Ibid, 113-115.

51 Silvia Spitta, Between Two Waters: Narratives of Transculturation in Latin America (Houston: Rice University Press, 1995), p. 6.
} 
At this stage in the discourse a certain degree of fragmentation is inevitable. Mudéjar, although a subject of serious study for well over a century, has only become a subject of importance in Latin America over the last thirty years. This is in contrast to Spain, where a serious discussion of Mudéjar has been in place since the nineteenth century. The origins of Mudéjar in Spain open up the political and cultural issues pertaining to the Reconquista and the forced conversion of Muslims. Research into its origins focuses on the Moorish presence, the politics of conquest, and the assimilation of Islamic subjects into Spanish society. ${ }^{52}$ In the case of Spain, Mudéjar has been equated with the Moorish craftsmen themselves; their presence within Christian Spain parallels the persistence of Islamic design elements in the built environment. According to historians of Mudéjar in Spain, the resulting Mudéjar style was more a product of political maneuvering than a mix of two cultures. The decision to allow the conquered Muslims to remain in the country, coupled with reliance upon them for crafts and design, resulted in the mix of Islamic and Christian design forms. The bodies of the laborers are granted agency, as if the physical presence of Muslim workers guarantees that the resulting structure is indeed "Islamic." Confusing the subject further is the addition of Christians and Jews to the story of Spanish Mudéjar. Only after the signatures of nonMuslim artisans were discovered on Mudéjar woodcarvings was the term broadened to its present extent. ${ }^{53}$ If the body of the worker determines the culture of an architectural style, then what culture can claim Mudéjar? After the term was expanded past the strictly religious definition, it was possible for it to be recognized in Latin America, where all Mudéjar structures were built by non-Muslims.

In the case of the relationship between Spain and its former colonies, Mudéjar has had to navigate postcolonial discourses as well as the various approaches that have served Islamic art history and Spanish national history. Theories of cultural contact have arisen to explain the architectural forms that developed in the wake of the conquest. Transculturation, the complex intermingling of disparate cultural elements, has had a significant impact on the way that Mudéjar's journey from post-Muslim Spain to Latin America has been reinterpreted. The words that have come to describe the distinct approaches, survival and reminiscence, reflect the end products of these processes. The fundamental question raised by the terminological distinction is more than the traditional one of agency - either of the conquering culture or the occupied one. It is also one of origins and the artistic nature of the Mudéjar fragments themselves. Mudéjar can be read as a record of the interactions between different cultures and a model for how cultural conflict can generate new knowledge.

This new knowledge, generated from the border, frontier, or periphery, illustrates how visual language - ornamentation and design - can be transmitted from one culture to another. The end result of such a journey is a connection between otherwise entirely disparate groups of people. In this case, Mudéjar connects the architecture of the Islamic world with that of Latin America, two cultures that have little else in common. Ortíz' theory of transculturation allows for an understanding of how a style of art and architecture could adapt in the face of cultural conflict. Islamic design and ornamentation survived religious persecution in Europe and mass extinction in the New World colonies, becoming the style known throughout the Spanish-speaking world as Mudéjar. Although it is possible to misuse the term transculturation, especially as it was originated to describe a specific Cuban

\footnotetext{
52 See David Raizman's "The Church of Santa Cruz and the Beginnings of Mudéjar Architecture in Toledo" (Gesta, 1999) and Katrin Kogman-Appel's "Hebrew Manuscript Painting in Late Medieval Spain: Signs of a Culture in Transition" (The Art Bulletin, 2002) for two good analyses of the origins of Islamic design in Spain.

53 Raizman, "The Church of Santa Cruz and the Beginnings of Mudéjar Architecture in Toledo," 137.
} 
context, I would argue that the process is at the root of any extended clash of cultures. The result of transculturation is a hybrid product - tobacco and sugar in the case of Cuba - that retains something of the originals. The give-and-take process that transformed agriculture on the Caribbean island is fundamentally the same as that which produced Mudéjar architecture in Spain and Latin America. Transculturation is, in a sense, a precursor to late twentieth-century globalization. By understanding how this process worked historically, it is possible for us to gain new insight into the transcultural dynamics in progress today. 


\section{(cc) EY-NG-ND}

This work is licensed under a Creative Commons Attribution-Noncommercial-No Derivative Works 3.0 United States License.

\section{ULIS D-Sork}

This journal is operated by the University Library System of the University of Pittsburgh as part of its D-Scribe Digital Publishing Program, and is co-sponsored by the University of Pittsburgh Press. 